Article

\title{
Gadamer, Levinas, and the Hermeneutic Ontology of Ethics
}

\author{
Christopher King \\ Department of Religion and Philosophy, Christian Brothers University, Memphis, TN 38104, USA; \\ cking8@cbu.edu
}

Received: 1 July 2019; Accepted: 11 August 2019; Published: 14 August 2019

\begin{abstract}
Much debate has been held over the question of whether Hans-Georg Gadamer's hermeneutic approach to ethics and the other can do justice to the alterity of the other, as exemplified in Emmanuel Levinas's approach to ethics as first philosophy. The challenge to Gadamer and to hermeneutics more generally, comes obliquely from Levinas and more directly, from Robert Bernasconi, who argues that Gadamer cannot account for an otherness that ends in incomprehensibility as one finds in encounters between persons of asymmetrical power relations-oppressed and oppressor, privileged and marginalized. Bernasconi's critique has resulted in a flurry of hermeneutic responses that insist that Gadamer's hermeneutics can, if understood in the right way, accommodate the other and serve as the foundation for robust ethical treatment of the other. I argue in this paper that participants in this debate have been insufficiently attentive to the ontologies that underlie the accounts of self and other in Gadamer and in Levinas. Because Gadamer and Levinas begin from different ontologies, their accounts of ethics and of the ground of ethics differ.
\end{abstract}

Keywords: Gadamer; Levinas; hermeneutics; ethics; ontology

\section{Bernasconi's Challenge to Hermeneutics}

Robert Bernasconi's essay, "You Don't Know What I'm Talking About: Alterity and the Hermeneutic Ideal," critiques Gadamer's hermeneutic conception of dialogues from a Levinasian perspective. ${ }^{1}$ Bernasconi's central contention is that Gadamer's model of dialogue diminishes the alterity required to respect the other and her claim as truly other. Gadamer views dialogue between persons as a central manifestation of the event of understanding, which he describes as a movement that begins in the prior continuity of traditions and language, which becomes disrupted in the encounter with otherness and resolves in the integration of that otherness into a fuller linguistic understanding. ${ }^{2}$ Gadamer describes a conversation or dialogue as requiring that both partners must be attuned not to each other as individuals, but to the subject matter at hand. In other words, in a true dialogue, the process of understanding does not involve understanding the other person as such, in her subjectivity, but rather it involves understanding the other person's claim, that is, what is said. The otherness that is presented in dialogue, then, is not the otherness of the person but of the

1 Bernasconi mentions in a note that while his argument is not Levinas's argument, strictly speaking, it does come from a Levinasian perspective (Bernasconi, 1995 [1]).

2 See Gadamer, 2004 [2] (pp. 347-348): "If a new experience of an object occurs to us, this means that hitherto we have not seen the thing correctly and now know it better. Thus the negativity of experience has a curiously productive meaning. It is not simply that we see through a deception and hence make a correction, but we acquire a comprehensive knowledge." See also Grondin, 2002 [3] (p. 44): "We start off with vague anticipations of the whole, which are, however, revised the more we engage the text and the subject matter itself. The basic hermeneutic experience (in the strong sense of Erfahrung), Gadamer will argue, is the experience that our anticipations of understanding have been shattered." 
claim. ${ }^{3}$ Thus Gadamer describes the true conversation as the creation of a shared language in which both dialogue partners are participants of the bringing to presence the common subject matter. ${ }^{4}$

Bernasconi takes issue with this account, arguing that the integration of otherness into a horizon of understanding serves ultimately to assimilate the other's views into one's own, without recognizing that some differences-some otherness—cannot be fused with one's own horizon. Bernasconi envisions a conversation in which the horizons of the interlocutors are so far removed from one another that one says to the other, "you don't know what I'm talking about." In other words, you don't have the frame of reference to understand me or to respond adequately to my claims. Bernasconi unpacks this a bit further, writing, "The phrase says, 'You cannot be yourself and understand me.' It not only says 'this is you': it also implies 'you ought to change,' and yet at the same time acknowledges that the change won't-in a sense, can't-take place. Women say it to men; the poor say it to the rich; the victim says it to the oppressor; the target of racism says it to the racist" (Bernasconi, 1995 [1]). These latter examples give concrete teeth to Bernasconi's claim that conversations are often neither grounded in nor directed at understanding, especially when power structures are involved. In these cases, one interlocutor, rather than seeking to understand, is seeking, through language, to objectify, to manipulate, and to further subjugate that other. The response-you don't know what I'm talking about-expresses the idea that when the other's claim is integrated into my horizon of knowledge, the other is thereby reduced to the categories of the same, to use Levinas's language. For Levinas, as well as for Bernasconi, this fails to do justice to the other by mitigating her alterity and her claim against the subject.

\section{Defenses of the Hermeneutic Project}

Defenses of Gadamer's hermeneutic account from Bernasconi's critique have come from Lawrence Schmidt, Monica Vilhauer, Joseph Gruber, and Constantin-Alexander Mehmel, among others. In different ways, each of these commenters point out that Gadamer is much more sensitive to the question of alterity and respect for the other than Bernasconi acknowledges. After all, Gadamer writes, "In human relations the important thing is ... to experience the Thou truly as a Thou-i.e., not to overlook his claim but to let him really say something to us ... Openness to the other, then, involves recognizing that I myself must accept some things that are against me, even though no one else forces me to do so" (Gadamer, 2002 [2]). On the basis of these claims, it appears that Gadamer really does place importance on being put into question by the other and by having one's expectations broken by the other. In this vein, Gruber writes, "The foundation of hermeneutical engagement, experience, is for Gadamer a negative correction, a calling up short, with which other challenges the listener. Contrary to Bernasconi's claims, but enabling the challenges that he wants the other to issue to the listener, Gadamer's hermeneutics allow for alterity in a full sense, but a sense that can be understood, however, imperfectly and in however many slowly developing conversations" (Gruber, 2014 [5]). The approach that is most often taken, then, in defending Gadamer's hermeneutics is to show how what Gadamer says should alleviate the concerns of the Levinasian critique. If Bernasconi wants Gadamer to be more sensitive to the alterity of the other, defenders of Gadamer have ample material to cite that demonstrates his respect for the other.

A second approach, taken by Mehmel, is to admit that irrespective of what Gadamer says in places, his hermeneutic model of understanding does in fact commit him to reducing the absolute alterity of the other. Despite this, Mehmel argues that there are resources in Gadamer that can preserve the otherness of concrete persons. Specifically, Mehmel thinks that while Gadamer doesn't himself make a sufficient distinction between treating the other as person and the other as text, his hermeneutics can

3 Gadamer does, however emphasize that it is important "to experience the Thou truly as a Thou-i.e., not to overlook his claim but to let him really say something to us." Gadamer, 2004 [2] (p. 355). Here, though, Gadamer maintains that the experience of the Thou is the experience of the Thou's claim.

4 See Gadamer, 2006, [4] (p. 359): "communication between humans creates a shared language just as much as it presupposes one." 
accommodate that distinction. ${ }^{5}$ Mehmel points out that Gadamer builds his account of understanding texts on the model of conversation. ${ }^{6}$ But Gadamer's hermeneutics of the text is designed precisely to overcome a model of hermeneutics that views the text as completely alien to one's own understanding. ${ }^{7}$ He wants to show instead that we are inextricably bound to history and texts by virtue of the tradition in which we participate. ${ }^{8}$ Bernasconi identifies this move to reduce the foreignness of history and puts the issue this way: "Gadamer employs the parallel between dialogue and the hermeneutic text in order to diminish the sense of alterity" (Bernasconi, 1995 [1]).

Mehmel picks up on this parallel and argues that it is problematic to think of interpersonal dialogue along the same lines as dialogue with a text. This is because "texts are enduringly fixed expressions of life" (Gadamer, 2004 [2]), as Gadamer puts it, meaning that the text cannot itself correct one's interpretation in the way that can happen in a living conversation. The dialogue with the text begins with the interpreter's anticipations of meaning, many of which get negated and transformed in the encounter with the text; then, the interpreter comes to an understanding of the text in a new, more holistic horizon. The interpreter does have her horizon changed in the encounter with the text, but once it is changed in the reading, it is no longer forced to change, and one's understanding of the text can thenceforth remain static. Mehmel notes accordingly that "the act of reconstructing the text's voice amounts to a closure of meaning" (Mehmel, 2016 [6]). If Gadamer were to maintain that the dialogue with the other is an exact parallel to the dialogue with the text, Bernasconi would be correct in his account of Gadamer's hermeneutics.

Mehmel argues that while Gadamer does hold to an important difference between textual dialogue and interpersonal dialogue, he does not consistently bring this difference out in his writings. Thus, attending to the difference in detail would be helpful to clearly show why conversation with persons does not result in a closure of meaning in the way that reading a text does. Beyond the fact that the person before me can correct my interpretation of her, Mehmel argues that for Gadamer, the encounter with the embodied presence of the other person is unique in its ability to put me into question. He quotes a later text of Gadamer as evidence for this claim:

The mere presence of the other before whom we stand helps us break up our own bias and narrowness, even before he opens his mouth to make a reply. That which becomes a dialogical experience for us here is not limited to the sphere of arguments and counter-arguments, the exchange and unification of which may be the end of meaning of every confrontation. Rather ... there is something else in this experience, namely a potentiality for being other that lies beyond every coming to agreement about what is common. (Gadamer, 1989 [7])

Mehmel takes this account of the interpersonal dialogue in the presence of the other to commit Gadamer to a view that there is something distinct about the embodied presence of the other person that makes that other person unassimilable. Mehmel claims, "Even if Gadamer draws on a far less radical understanding of the Other, he could still subscribe to Lévinas's claim that the Other's presence evokes a response in an unique manner, something the text cannot do" (Mehmel, 2016 [6]). Hence,

5 See Mehmel, 2016 [6] (p. 1): "I argue that Gadamer can accommodate an Other that is not assimilated but appreciated. My claim is thereby not that Bernasconi's reading of Gadamer is completely misplaced. Rather, I suggest that we should no longer neglect the unique status of a dialogue with the Other as a person, as Gadamer himself does, but instead truly distinguish it from a dialogue with the Other as a text."

6 See Gadamer, 2004 [2] (p. 387): "Everything we have said characterizing the situation of two people coming to an understanding in conversation has a genuine application to hermeneutics, which is concerned with understanding texts." See also, Gadamer, 2004 [2] (p. 466): "the way tradition is understood and expressed ever anew in language is an event no less genuine than living conversation."

7 See Gadamer, 2004 [2] (p. 179), for Gadamer's account of the romantic hermeneutics he will argue against: "Schleiermacher's idea of a universal hermeneutics starts from this: that the experience of the alien and the possibility of misunderstanding is universal."

8 See Gadamer, 2004 [2] (p. 291): “Understanding is to be thought of less as a subjective act than as participating in an event of tradition, a process of transmission in which past and present are constantly mediated." 
Mehmel concludes Gadamer's hermeneutic project and the ethics it suggests can be salvaged and defended against Bernasconi's critique because Gadamer, like Levinas, allows for the other person to continually put oneself into question.

\section{The Ontology of Language in Gadamer}

In contrast to Mehmel, I argue that the ethical responsibility model championed by Levinas will fault Gadamer's account with being still too Hegelian-too committed to comprehension and the reduction of otherness into familiarity. From the point of view of Bernasconi and Levinas, in order for Gadamer's model to more closely approach truth, it needs to include in its account the radicality of the encounter with the other person which as such can never be reduced to thematization. Gadamer, for his part, would admit, on one level, that the encounter with the other person is always one in which my own projects would be negated. In what appears to be a concession to the Levinasian point of view, and as quoted by Mehmel above, Gadamer writes, "The mere presence of the other before whom we stand helps us to break up our own bias and narrowness, even before he opens his mouth to make a reply" (Gadamer, 1989 [7]). This sounds like a restatement of Levinas's claim that the expressive presence of the face of the other functions to invert the subject's intentional consciousness. Yet Gadamer ensures that this experience is subsumed under the rubric of dialogical experience. This experience in the context of dialogue, which he also calls experience of "the potentiality for being other" (Gadamer, 1989 [7]), does not come from the other herself, on Gadamer's view. Instead, it comes from the situation of dialogue, even if it precedes the act of speaking.

Gadamer explains further what he means here by asking, "Who has not had the experience- especially before the other whom we want to persuade — of how the reasons that one had for one's own view, and even the reasons that speak against one's own view rush into words" (Gadamer, 1989 [7]). The critical impulse in dialogue comes not from subjectivity nor from the other person who faces me, but from the emergence of the subject matter, the Sache, as the manifestation of the true, what Gadamer sees as the deep connection between language and thought. ${ }^{9}$ It is the truth of the subject matter itself which comes to language and which leads the dialogue. ${ }^{10}$ Hence, the experience of being-other, of the breaking up of one's own biases, confronts the self from the standpoint of the Sache in question rather than from the face of the other. It is not responsibility for the other person which is commanded but rather the openness to change one's own views. While this could include a recognition of responsibility for the other, it certainly need not be related to responsibility at all.

Although Gadamer does not directly deal with Levinas's writings, he does indicate that he is familiar with Levinas's views and has an appreciation of them. In his essay "Hermeneutics and Logocentrism," Gadamer anticipates his interlocutor Jacques Derrida's objection to the hermeneutic ontology of understanding which would claim that "understanding always turns into appropriation and so involves a covering-up of otherness. Levinas, too, values this argument highly, so it is definitely an observation that one cannot dismiss" (Gadamer, 1989 [8]). However, Gadamer continues on to give a criticism of the viewpoint that understanding otherness is always a return to self-identification in suggesting "that to make an assumption that such identification occurs within understanding is to disclose a position that is idealistic and logocentric, one we had already left behind after World War I in our revisions and criticisms of idealism" (Gadamer, 1989 [8]). In other words, Gadamer thinks that the criticism that Derrida and Levinas would make against him is in fact a criticism of a position that he does not hold. It is rather a criticism of German idealism in the vein of Hegel which seeks to confirm

9 See Gadamer, 2004 [2] (p. 425): "The inwardness of the word, which constitutes the inner unity of thought and speech, is the reason for its being easy to miss the direct and unreflective character of the 'word' ... Hence the appearance is created that the formation of the word arises from the mind's being directed toward itself. In fact, there is no reflection when the word is formed, for the word is not expressing the mind but the thing intended ... The thought seeking expression refers not to the mind but to the thing."

10 See Gadamer, 2004 [2] (p. 385): "conversation has a spirit of its own, and ... the language in which it is conducted bears its own truth within it-i.e., ... it allows something to 'emerge' which henceforth exists." 
a perfect and complete identification of self with self in absolute knowledge. Gadamer thinks that twentieth-century philosophy has moved irrevocably past such a position, primarily because of the recognition that human beings only appear to themselves through language, and language is always a finite and imperfect mirror through which to view oneself.

When Gadamer speaks of the achievement of self-understanding, this self-understanding "involves a moment of 'loss of self'" (Gadamer, 1976 [9]) which is never fully recovered, but is rather mediated back to the self through the play of language over which no one is master. Thus, Gadamer would suggest that the intentionality which Levinas seeks to overthrow through the encounter with the face in non-intentional consciousness has already been overthrown in the taking seriously of language. Understanding is now not achieved through the dominance of the intention which would seek to reflect all things back into itself, but rather through language, which both frustrates idealist self-confirmation and is the condition which makes possible genuine relationships with others. Because language is the medium through which truth comes to presence, persons cannot rightly relate to one another in another way than through the reciprocity of dialogue.

Therefore, Gadamer's defense against criticisms of idealism also contains an argument against the Levinasian viewpoint which claims that the self is unilaterally responsible for the other. Gadamer's own critique would suggest that in setting up the self as unconditional responsibility, Levinas actually robs the self of being able to understand the other in dialogue. Gadamer suggests that attempting to escape "the mutuality of such a relation changes this relationship and destroys its moral bond" (Gadamer, 2004 [2]). Thus, Gadamer would claim that the self cannot be in a genuine relationship with others if the self is the sole responsible party, if the concrete other does not participate in dialogue.

On Gadamer's view, genuine sociality cannot occur apart from truth presenting itself in dialogical situations. In a similar manner, Gerald Bruns thinks Gadamer "might fault Levinas for setting the ethical relation too sharply against hermeneutics-for having, finally, too abstract a conception of the ethical" (Bruns, 2004 [10]). In other words, because Levinas sets the condition of responsibility prior to the empirical interchange of language, ethics is abstracted from the concreteness of everyday life which is only made present through language. For Gadamer, Levinas's radicalized ethics as first philosophy would actually undermine ethics because it rejects the hermeneutic condition of understanding others in historical relationships. If ethics were to be operative at a level wholly prior to the conversation of a subject matter, there would be no content to ethics. As Bruns puts it, "from Gadamer's perspective Levinas's conception of the ethical is too purely ethical, not sufficiently social (not sufficiently historicized)" (Bruns, 2004 [10]). Gadamer will think that because Levinas grounds the self-other relation solely in the disruptive moment prior to dialogue, he cannot sustain genuine self-other relations which must thrive in the language of the world.

\section{The Priority of the Face in Levinas}

From Levinas's own point of view, hermeneutics does have a legitimate place in understanding and relating to the world, but hermeneutics does not exhaust the ways in which humans can interact with reality. Levinas writes, "In all its analyses of language contemporary philosophy insists, and indeed rightly, on its hermeneutical structure and on the cultural effort of the incarnate being that that expresses itself" (Levinas, 1996 [11]). However, while accepting a hermeneutics of culture and language, Levinas argues the other person presents the self with a prevenient discontinuity that is not mediated by tradition and language. His claim is that a hermeneutics of the other person is derivative of the primary expressiveness of the face of the other. ${ }^{11}$

11 See Levinas, 1996 [11] (p. 52): “In other words, expression, before being a celebration of being, is a relationship with him to whom I express the expression and whose presence is already required for my cultural gesture of expression to be produced. The Other (Autrui) who faces me is not included in the totality of being expressed." 
For Levinas, the primary function of the expression of the face is to put into question the I, or to invert and shatter the intentional arrow of the subject. Note here the consonance of what Levinas says with Gadamer's view of language as conditioning consciousness rather than being conditioned by it. However, Levinas maintains, in contrast to Gadamer, that the fundamental separation between persons, between I and other, is what makes possible language and that language as relation does not negate or overcome this separation. ${ }^{12}$ Levinas thus rejects the concept of participation, both in ontology and in sociality as well. Levinas writes,

The relationship of language implies transcendence, radical separation, the strangeness of the interlocutors, the revelation of the other to me. In other words, language is spoken where community between the terms of the relationship is wanting, where the common plane is wanting or is yet to be constituted. It takes place in this transcendence. Discourse is thus the experience of something absolutely foreign. (Levinas, 1969 [12])

Instead of language being the common bond of tradition in which subjects are absorbed, language in Levinas's view originates and is expressed from the other to the subject. It is the face itself which is the origin of language, apart from the linguistic capabilities of the other herself. ${ }^{13}$

Levinas thus rejects from the outset an ontology of the likes espoused by Gadamer which advocates the participation of two parties in the same ontological bond of language. For his part, Gadamer would deny that his hermeneutic ontology turns the other into a "second copy" of the I. Because humans share some things in common, such as language and tradition, need not lead to the claim that persons are reduced simply to their commonalities. Rather, these common traits make possible the access to the other. Communication would be impossible apart from the conditions which alike we share. Without dialogue, we could not learn of the otherness which exists from beyond our limited horizon. Yet from Levinas's point of view, a sociality grounded in the bond of language which exerts its agency over individuals does not escape the idealist tendency of the ego to understand the other as alter-ego. While Gadamer gives lip service to changing one's own views before the other, the other is always understood in terms of the language which is shared in common. For Levinas, the agency of the Sache, which presents itself in language, is insufficient to combat the ego's predisposition to reduce the other to the same.

One clear way to illustrate the difference between a model of sociality constituted in reciprocity and Levinas's view of sociality as grounded in the expressive presence of the face is by focusing on the situation of dialogue. It is this analysis which will bear out Levinas's fundamental disagreement with Gadamer regarding the social relation. Though Levinas does not anywhere explicitly address Gadamer, what he does say about the place of dialogue in sociality is illustrative. Levinas describes ordinary dialogue as "the empirical reality of inter-human speaking," a situation in which, "for each of the interlocutors, speaking would consist in entering into the thought of the other, in fitting into it" (Levinas, 1998 [14]). Levinas's account of what dialogue is here comes quite close to the way Gadamer sees the dialogical relationship of persons who come together through the Sache. Levinas, however, contests that this position of dialogue is the genuine locus of sociality. He will admit that otherness is posited in dialogue, but he notes, with Gadamer, that this otherness is only one stage in the conversation. Hence, Levinas questions the primacy of dialogue thus construed:

12 See Levinas, 1969 [12] (p. 77): “in order to welcome revelation a being apt for this role of interlocutor, a separated being, is required."

13 Levinas rearticulates his account of language and expression in Otherwise than Being through the terms "saying" and "said." Roughly, the saying is the expressiveness found in the encounter with the other in the proximity of the face, while the said is the linguistic accretion of intelligible propositions and claims. Saying is primordial sociality which is otherwise than being; the said is the philosophy which expresses that sociality in terms of being. See especially Levinas, 1981 [13] (pp. 6-7). I do not, however, have the space for a full analysis of the developments of language in this text. 
One must ask if this very discourse [dialogue], despite its allegedly interior scissions, does not already rest on a prior sociality with the other in which the interlocutors are distinct. It is necessary to ask if this effective, forgotten sociality is not nonetheless presupposed by the rupture, however provisional, between self and self, for the interior dialogue still to deserve the name dialogue. (Levinas, 1998 [14] $)^{14}$

Here, Levinas suggests that the situation of either interior or empirical dialogue, in which the partners are united in the subject matter, is derivative of the encounter with the face which demonstrates the true otherness of the persons from one another. ${ }^{15}$

This means that Levinas would think that Gadamer has misdescribed the enactment of the self-other relationship; on Levinas's view, Gadamer's hermeneutic ontology arrives "too late."16 Both Levinas and Gadamer claim that the self is in formation (in some sense) prior to self-reflection. Self-reflective consciousness always comes too late, for both thinkers, and therefore, finds itself always already underway. However, each thinker interprets this "always alreadyness" differently. For Gadamer, as we have seen, subjectivity is always already caught up in the continuity of (1) the flow of time, (2) language, and therefore, (3) tradition. The self is already a bridge, before it knows itself as self. For Levinas, on the other hand, subjectivity always already finds itself ruptured, accused, by its proximity to the other. It is always already a You, responsible for the other.

For Levinas, then, the primordial social relation of the face to face is constitutive of a non-totalizing ontology, which he prefers to call metaphysics. While for Gadamer, sociality is determined in large part by a more comprehensive ontological structure, for Levinas, sociality just is true ontology, if we may put it that way. ${ }^{17}$ Or rather, the sociality found in the face to face meeting between two human persons overturns all other totalizing ontologies. Instead of working from broad structure to specific applications of that structure, Levinas begins from the concrete situation of the confrontation of one face to another and spins out his entire project from the implications of that encounter. ${ }^{18}$ Levinas, then, rejects the Gadamerian claim that hermeneutic ontology is the medium out of which the relation to the other first unfolds. ${ }^{19}$

\section{Conclusions}

By way of conclusion, I return to Bernasconi's initial challenge to Gadamerian hermeneutics, his claim that Gadamer's theory "works to deprive alterity of its otherness prior to its appearance within the system" (Bernasconi, 1995 [1]). Bernasconi's worry that Gadamer's self assimilates the other is slightly misplaced, from a Levinasian point of view. For Levinas, ethics-responsibility-comes not from openness to listening to the other nor from a refusal of assimilation but from the expressive presence of the face which of itself commands responsibility for the other. For Levinas, then, Gadamer

14 Emphasis my own. See also Levinas, 1998 [14] (p. 164): “Does not the interior dialogue presuppose, beyond the representation of the other, a relationship to the other person as other, and not initially a relationship to the other already apperceived as the same through a reason that is universal from the start?"

15 See Dudiak, 2001 [15] (p. 146): “The possibility of interparadigmatic dialogue thus rests upon my capacity to recognize that responsibility for the other, which is (ethical) truth, founds and governs the truth of logos, precedes and founds dialogue as the possibility of any circulation of information."

16 See Levinas, 1987 [16] (p. 119): "consciousness is always late for the rendezvous with the neighbor."

17 While Levinas prefers the term metaphysics as a contrast to the term ontology, it is important for my argument that Levinas does give an underlying account of what is, which serves to ground his account of the self-other relation.

18 In the preface to Totality and Infinity, Levinas puts his method like this: "we can proceed from the experience of totality back to a situation where totality breaks up, a situation that conditions the totality itself. Such a situation is the gleam of exteriority in the face of the Other. The rigorously developed concept of this transcendence is expressed by the term infinity. This revelation of infinity does not lead to the acceptance of any dogmatic content, whose philosophical rationality cannot be argued for in the name of the transcendental truth of the idea of infinity. For the way we are describing to work back and remain on this side of objective certitude resembles what has come to be called the transcendental method (in which the technical procedures of transcendental idealism need not necessarily be comprised)." Levinas, 1969 [11] (pp. 24-25).

19 I hence argue for basic incompatibility of the two models, in contrast to the approach of Richard Shapcott, who, while comparing Gadamer with Derrida, argues for a complementarity between models that emphasize continuity on the one hand and discontinuity and rupture on the other. See Shapcott 2001 [17] (p. 194). 
goes wrong not because his account assimilates the other but because he misses the locus of the ethical relation-it is not dialogue which secures or can secure ethical relations, but the command of the face. Bernasconi's worry appears in an epistemological register rather than in an ethical one. His concern is to preserve epistemological difference and uncertainty in order that the other not be reduced to one's own conceptuality.

When the victim says to the oppressor, "You don't know what I'm talking about," what is the status of this encounter? On Gadamer's view, there should arise a subject matter from the dialogue itself that displaces both interlocutors and seeks a new understanding, even if no subsequent agreement takes place. Understanding that I do not or have not yet understood is also an appropriate outcome for dialogue. Yet for Levinas, the point of the encounter is not to come to a better understanding or even to undo a previous understanding. It is instead to find oneself responsible for the other who is in front of me.

Responders to Bernasconi such as Gruber and Mehmel highlight how Gadamer gives or can give epistemic distance to the other, thus thinking they have shown that uncertainty about the other also means respecting the other (Schmidt, 2000; Vilhauer, 2010 [18,19]). However, from Levinas's point of view, respecting the other is not simply preserving distance, but more fundamentally, it is about the responsibility that is engendered from the encounter with the expressive presence of the face. Hence, the Levinasian point of view will not be satisfied with any view that attempts to procure ethics from any maneuver or from any site other than the face of the other.

In terms of my response to the other, however, Bernasconi does capture Levinas's central contention. He writes, "If there is an appropriate response to the person who challenges me by refusing me the possibility of understanding, it lies in my finding myself judged and finding myself in this judgment, even if I may be unable to sustain myself in this stance for any time" (Bernasconi, 1998 [1]). The appropriate response, in other words, is not to understand that I do not understand, but instead is to be ethically moved in the accusation. Here, the affectivity of ethics precedes and founds the quest for understanding.

The outcome, then, of the challenge to Gadamer's hermeneutic approach to the other reveals less an accommodation of one view to the other and more a reassertion of the divergence in outlooks which is rooted finally in different conceptions of ontology. On Levinas's view, the Gadamerian appeal to dialogue is simply derivative of the true ground of sociality. Levinas does have a place for dialogue; it is located subsequent to and conditioned by the responsibility engendered by the face of the other. Likewise, Gadamer can affirm the importance of the radical interruption found in the presence of the other who faces me, but this interruption must be grounded in the being of the Sache, which comes to presence in language and overcome in the restoration of understanding.

Funding: This research received no external funding.

Conflicts of Interest: The author declares no conflict of interest.

\section{References}

1. Bernasconi, R. You Don't Know What I'm Talking About: Alterity and the Hermeneutic Ideal. In The Specter of Relativism. Truth, Dialogue, and Phronesis in Philosophical Hermeneutics; Schmidt, L.K., Ed.; Northwestern University Press: Evanston, IL, USA, 1995; pp. 178-194.

2. Gadamer, H.-G. Truth and Method, 2nd Revised ed.; Weinsheimer, J.; Marshall, D.G., Translators; Continuum: New York, NY, USA, 2004.

3. Grondin, J. Gadamer's Basic Understanding of Understanding. In The Cambridge Companion to Gadamer; Dostal, R.J., Ed.; Cambridge University Press: Cambridge, UK, 2002; pp. 36-51.

4. Gadamer, H.-G. The Incapacity for Conversation. Cont. Philos. Rev. 2006, 39, 351-359.

5. Gruber, J. Hermeneutic Availability and Respect for Alterity. Philos. Today 2014, 58, 23-38. [CrossRef]

6. Mehmel, C.-A. Possibility of Hermeneutic Conversation and Ethics. Theor. Prax. 2016, 4, 1-16. 
7. Gadamer, H.-G. Text and Interpretation. In Dialogue and Deconstruction: The Gadamer-Derrida Debate; Michelfelder, D.P., Palmer, R.E., Eds.; Schmidt, D.J.; Palmer, R.E., Translators; State University of New York Press: Albany, NY, USA, 1989; pp. 21-51.

8. Gadamer, H.-G. Hermeneutics and Logocentrism. In Dialogue and Deconstruction: The Gadamer-Derrida Debate; Michelfelder, D.P., Palmer, R.E., Eds. and Translators; State University of New York Press: Albany, NY, USA, 1989; pp. 114-125.

9. Gadamer, H.-G. Philosophical Hermeneutics; Linge, D.E., Ed. and Translator; University of California Press: Berkeley, CA, USA, 1976.

10. Bruns, G.R. On the Coherence of Hermeneutics and Ethics: An Essay on Gadamer and Levinas. In Gadamer's Repercussions: Reconsidering Philosophical Hermeneutics; Krajewski, B., Ed.; University of California Press: Berkeley, CA, USA, 2004; pp. 30-54.

11. Levinas, E. Meaning and Sense. In Basic Philosophical Writings; Peperzak, A., Critchley, S., Bernasconi, R., Eds.; Lingis, A., Translator; Duquesne University Press: Pittsburgh, PA, USA, 1996.

12. Levinas, E. Totality and Infinity; Lingis, A., Translator; Duquesne University Press: Pittsburgh, PA, USA, 1969.

13. Levinas, E. Otherwise than Being; Lingis, A., Translator; Duquesne University Press: Pittsburgh, PA, USA, 1981.

14. Levinas, E. Diachrony and Representation. In Entre Nous; Smith, M.B.; Harshav, B., Translators; Columbia University Press: New York, NY, USA, 1998; pp. 159-178.

15. Dudiak, J. The Intrigue of Ethics: A Reading of the Idea of Discourse in the Thought of Emmanuel Levinas; Fordham University Press: New York, NY, USA, 2001.

16. Levinas, E. Language and Proximity. In Collected Philosophical Papers; Lingis, A., Translator; Duquesne University Press: Pittsburgh, PA, USA, 1987; pp. 109-126.

17. Shapcott, R. Justice, Community, and Dialogue in International Relations; Cambridge University Press: Cambridge, UK, 2001.

18. Schmidt, L.K. Respecting Others: The Hermeneutic Virtue. Cont. Philos. Rev. 2000, 33, 359-379. [CrossRef]

19. Vilhauer, M. Gadamer's Ethics of Play: Hermeneutics and the Other; Lexington Books: Lanham, MD, USA, 2010.

(C) 2019 by the author. Licensee MDPI, Basel, Switzerland. This article is an open access article distributed under the terms and conditions of the Creative Commons Attribution (CC BY) license (http://creativecommons.org/licenses/by/4.0/). 